\title{
ECONOMIC GROWTH, AIR POLLUTION, AND GOVERNMENT ENVIRONMENTAL REGULATION: EVIDENCE FROM 287 PREFECTURE-LEVEL CITIES IN CHINA
}

\author{
Jiandong $\mathrm{CHEN}^{1}$, Jie $\mathrm{QI}^{1}$, Ming GAO${ }^{1}$, Yijing $\mathrm{LI}^{1}$, Malin $\mathrm{SONG}^{2 *}$ \\ ${ }^{1}$ School of Public Administration, Southwestern University of Finance and Economics, \\ 611130 Chengdu, China \\ ${ }^{2}$ School of Statistics and Applied Mathematics, Anhui University of Finance and Economics, \\ 233030 Bengbu, China
}

Received 07 December 2020; accepted 28 February 2021

\begin{abstract}
Air pollution control is crucial for promoting the modernization of governance systems and efficiency. To address the subjective contrived factors and errors in the gross domestic product (GDP) data in traditional statistical almanacs, our study aims to construct a panel data model of 287 prefecture-level cities for the period from 1998-2016 (using objective nighttime light data). We also used government work report words related to environmental regulation to characterize the constraints of government environmental regulations. For this purpose, we used instrumental variables (to explore the relationship and interaction between air pollution and economic growth) and a model setting, with which we carried out regression analysis and robustness tests; the findings were validated using a transmission mechanism hypothesis. We found that that economic growth and air pollution positively influence each other and government environmental regulations significantly reduce air pollution. We also found that to achieve high economic development, environmental pollution must be controlled to avoid further damage to human and material capital. Furthermore, government environmental regulations can help improve the environmental comfort level and economic development quality.
\end{abstract}

Keywords: economic growth, $\mathrm{PM}_{2.5}$, air pollution, environmental governance, nighttime light data.

JEL Classification: Q53, Q56, R11, H83.

\section{Introduction}

Economic growth is a major driving force for national development and social progress, and no topic related to human livelihood can be discussed without the theme of economic growth. This is why the leaders of China and the U.S.A., as well as representatives of the world's largest developing and developed countries, have coincidentally proposed the idea

*Corresponding author. E-mail: songmartin@163.com

Copyright $\odot 2021$ The Author(s). Published by Vilnius Gediminas Technical University

This is an Open Access article distributed under the terms of the Creative Commons Attribution License (http://creativecommons. org/licenses/by/4.0/), which permits unrestricted use, distribution, and reproduction in any medium, provided the original author and source are credited. 
of boosting their economies in the process of fighting the COVID-19 pandemic. However, the direct consequence of economic growth brought about by large-scale industrialization is air pollution (Shi et al., 2020; Fan \& Xu, 2020), which affects the health and life expectancy of the population and also decreases their emotional wellbeing (He et al., 2020; Song et al., 2019; Maji et al., 2018; Xu et al., 2017).

As living standards improve, there are increasingly higher demands on the surrounding natural environment. On September 10, 2013, to meet people's growing desire for a better life, China proposed that the Ministry of Environmental Protection of the P.R.C. (MEP) would reformulate environmental protection standards in 2013. China issued announcements for six national environmental protection standards, including specifications and test procedures for an ambient air quality continuous automated monitoring system for $\mathrm{PM}_{10}$ and $\mathrm{PM}_{2.5}$ while the State Council issued and promulgated the Air Pollution Prevention and Control Action Plan (hereinafter referred to as "Air Ten Terms"). The goal was to decrease the inhalable particle concentration in cities at the prefecture-level (and above) by more than $10 \%$ (of the concentration recorded for 2012) by the end of 2017. At the same time, revisions to the new Environmental Protection Law in 2014 forced the government to discontinue its previous assessment that had the gross domestic product (GDP) as its only criterion; indicators, such as the environmental index, were later included in the assessment to improve its accuracy. In view of this, the national government has proposed that environmental governance is an indispensable component of the modernization of the national governance system and its efficiency, such that it is crucial to expand environmental governance. This paper focuses on the dual impact of government environmental regulations on air pollution and economic development with respect to the national development strategy previously implemented to add value to lucid waters and lush mountains.

In terms of existing references on economic growth and environmental pollution, most studies focus on the provincial level (Xu et al., 2016, 2019; Wang et al., 2017; Wu et al., 2020); these studies smooth out the heterogeneity at the local city level, thereby preventing the need for a heterogeneity analysis. In this study, a comprehensive meteorological (satellite) city database is constructed by collating the China City Statistical Yearbook using nighttime light data matched at the local city level.

Nighttime light data has been widely used as an appropriate proxy variable for measurements of economic activity (Henderson et al., 2012). Instead of using the GDP, we can more accurately measure the domestic economic activity in China using nighttime light data (Henderson et al., 2012; Ma et al., 2012, Ji et al., 2019b). First, GDP measurements are systematically biased because there are many smaller components not included in the GDP, excluding components from governmental or statistical departments, which partially reduces the output of the GDP (Zhang \& Seto, 2011). Second, the "tournament of promotion" caused by the GDP forces local governments to inflate their GDP figures through various forms of misreporting, concealing, and omissions to accelerate their promotions. Existing GDP statistics are likely to exclude the contribution of the areas that cannot be counted due to their small GDP values. In contrast, changes in administrative divisions may lead to substantial fluctuations in the GDP of the same region, thereby causing biases in the data. Fourth, a com- 
parison of world economic activities among the "basket of currencies" is the most common method to evaluate economic performance. While these types of comparisons are prone to bias or a loss of purchasing power, the use of nighttime lighting as an objective data source can be a good solution to difficult classification standards across countries and the use of uniform standards for fitting. At the same time, nighttime light data can be used to accurately locate cities and counties by image cutting; this can be used to perform heterogeneity analysis (Zhao et al., 2019; Kacprzyk \& Kuchta, 2020). However, the use of nighttime light data is predominantly limited to the period from 1992-2013 (Wang et al., 2014; Zhao et al., 2019; Ji et al., 2019a) Most existing studies use Defense Meteorological Satellite Program/Operational Linescan System (DMSP/OLS) satellite data to compile the nighttime light data. However, studies using DMSP/OLS satellite data are only available up to 2013. Studies using National Polar-Orbiting Partnership/Visible and Infrared Imager/Radiometer Suite (NPP/VIIRS) data (Yue et al., 2020) have proven to be useful; however, using the two datasets separately leads to a time break and isolation, such that several studies have integrated the two datasets. The simulation and processing of the data has been previously carried out in a disjointed manner with large samples obtained over a long period. In particular, policy effects from the new environmental standards and the "Air Ten Terms" promulgated in 2013 cannot be estimated using the DMSP/OLS and NPP/VIIRS satellite data alone.

Based on the innovative use of the method for processing and integrating the DMSP/ OLS and NPP/VIIRS datasets (Chen et al., 2020a) in this study, we obtained the annual total nighttime light intensity averages from the nighttime light data for 287 prefecture-level cities in China. Due to the missing values in the main control variables before 1998, such as the population density and road person ratio, data for 1992-1998 were excluded. The comprehensive database constructed in this study has a longer span and a larger sample size, which can better reflect the underlying statistical patterns.

The main research innovations and possible contributions of this study are as follows: 1) most research and development studies using satellite data have focused on the provincial level. In this paper, for the first time, satellite data are used to extend analyses to prefecturelevel cities from 1998 to 2016, which can better reflect the heterogeneity between regions. 2) Objective satellite data and $\mathrm{PM}_{2.5}$ data were used for regression, as well as the use of the objective air flow coefficient and word frequencies in government work reports as instrumental variables to alleviate the endogeneity problem and reduce data errors caused by statistics. 3) Based on the physical capital and human capital two channels mechanism analysis, we found that for a Chinese urban population between 1 and 5 million, the urban development will be more dependent on its physical capital input elements; with a population of more than 5 million, the demand for human capital will increase dramatically. These results on urban development in developing countries provides a new train of thought and direction.

The remainder of this paper is structured as follows. Section 1 provides a literature review. Section 2 presents the methodology and model construction. Section 3 details the econometric regression and analyzes the results. Finally, last Section summarizes this study and provides targeted policy recommendations. 


\section{Literature review}

In terms of the existing literature on the relationship between economic development and air pollution, studies have focused on the impact that economic development has on the environment (Ouyang et al., 2019; Liu et al., 2019) and the negative effects that environmental pollution has on economic development (Wolde-Rufael \& Idowu, 2017; Jiang et al., 2018; Masiol et al., 2017).

To explore the impact that environmental pollution has on economic growth, Grossman and Krueger $(1991,1995)$ proposed multiple innovations; however, there are divergent and varying perspectives on whether the Kuznets effect is an inverted U- or N-type (Stern \& Zha, 2016; Egbetokun et al., 2020; Hao et al., 2018; Wang \& Komonpipat, 2020). This disagreement may be due to inconsistent data (with respect to inconsistent years) used by previous studies, as well as statistical bias and a lack of regional heterogeneity inclusion. Therefore, this study uses purely objective nighttime light data to verify the environmental Kuznets effect.

When discussing the negative effects of economic development on the environment, previous studies (Wang et al., 2018; Yan et al., 2020; Jiang et al., 2018) indicates that the use of nature's self-regulating function mainly reflects the impact of unconstrained pollution emissions on economic growth; this reduces the cost of emissions and increases the factor inputs to enhance the economic output. The effect on economic growth is positive within the limits of natural tolerance; however, once the threshold of natural tolerance is exceeded, pollution emissions will have a negative impact on economic growth. These negative effects mainly include two aspects: for material capital, pollution emissions will lead to the consumption or destruction of part of the material capital, thus increasing the cost of production and operation; for labor capital, pollution emissions will reduce people's sense of happiness and satisfaction, destroy the accumulation of human capital, and reduce a city's clustering effect, thus limiting incremental returns to scale in cities. Furthermore, the input-output ratio of the labor-capital factor declines, thereby slowing the pace of economic development. In general, the ultimate effect of unconstrained pollution emissions on economic development depends on the sum of all affected factors. The ultimate impact of such uncontrolled pollution emissions on economic development depends on the relative changes in the positive and negative effects. Therefore, we analyzed the specific transmission mechanism within the impact that smog pollution has on China's economic development in terms of both material and human capital.

To characterize air pollution, previous studies have used conventional pollutants, such as $\mathrm{SO}_{2}, \mathrm{CO}_{2}$, CO, total suspended particles (TSP), air pollution index (API), air quality index (AQI), $\mathrm{PM}_{10}$ (Zhang \& Chen, 2020; Ren \& Matsumoto, 2020; Dubey et al., 2019; Iacobuta et al., 2019), and $\mathrm{PM}_{2.5}$ (Hao et al., 2018; Zheng \& Xu, 2020). However, compared with conventional pollutants, $\mathrm{PM}_{2.5}$ accounts for a larger share of air pollution and is also an important indicator of residential well-being and health (Song et al., 2017, 2019). Therefore, $\mathrm{PM}_{2.5}$ was also selected as characterization data for air pollution in the air quality validation and analysis.

Many studies have focused on the topic of government environmental regulations based on the implementation effects of policies enacted by the government (Lin, 2017; Lin \& Jia, 2019; Wang \& Zhu, 2020). Empirical studies on air pollution have been conducted at macro- 
and meso-level scales using provincial- or municipal-level data (Wu et al., 2020; Liu et al., 2019; Tan et al., 2018). Furthermore, previous studies have mainly proposed theoretical policy hypotheses on how the government can address air pollution; these include hypotheses on certain issues, such as carbon taxes, carbon emissions trading rights, emissions rights, and carbon trading markets (Han \& Li, 2020; Liu et al., 2019; Tan et al., 2018; Zhang et al., 2020; Hanaoka \& Masui, 2020; Liu \& Lu, 2015). However, textual analyses of environmental governance in government work reports have seldom investigated the reasons for the selection of a certain starting year for environmental governance. In this study, we used the word frequency of environmental governance in government work reports as an instrumental variable (and to derive the air flow coefficient) to investigate the reasons for selecting a certain starting year for environmental governance with respect to the government work report.

\section{Methodology and model construction}

\subsection{Instrumental variables}

Instrumental variables are widely used in empirical research and analyses as a basic and necessary tool in econometrics (Gong et al., 2020; Lin, 2017). The endogeneity of air pollution variables is an issue that must be discussed when developing an econometric empirical model to analyze the impact of air pollution on economic development. Specifically, environmental pollution may slow down economic development by decelerating urbanization and damaging human and material capital accumulation channels. In contrast, economic development itself may affect environmental pollution through scale, technology, and structural effects. The endogeneity problem can be eliminated by selecting instrumental variables for supplementary regression. Therefore, we selected the air flow coefficient as an instrumental variable and used text mining to extract the corresponding environment-related words (including environment, pollution, emissions reduction, environmental protection, pollution, energy consumption, emissions reduction, sewage, ecological, green, low-carbon, air, chemical oxygen demand, and $\mathrm{SO}_{2}$ emissions, among others) in the provincial government work reports of each prefecture-level city based on Hering and Poncet (2014) $\left(\mathrm{CO}_{2}, \mathrm{PM}_{10}, \mathrm{PM}_{2.5}, \mathrm{API}\right.$, and AQI). Then, we calculated the proportion of the total words in the report and multiplied it by the share of secondary industries at the city-level as the instrumental variables. The air flow coefficient can be used as an instrumental variable for haze pollution because larger values indicate increased air mobility, which is negatively correlated with haze pollution and satisfies the correlation assumption for valid instrumental variables (Hering \& Poncet, 2014). In contrast, boundary layer heights are determined by complex meteorological systems and geographic conditions, thus satisfying the assumption of exogeneity in the effective instrumental variables (Broner et al., 2012).

\subsection{Data sources and description}

To accurately assess the effects of government environmental regulations and their influence mechanisms, we synthesized several statistical datasets to ultimately construct a comprehensive database combining satellite remote sensing data, meteorological and pollution data, and basic data at city and industry levels with the following data indicators and sources. 
First, we obtained satellite remote sensing data from the DMSP/OLS and NPP/VIIRS total nighttime light intensity data from the National Geophysical Data Center (NGDC) and the National Oceanic and Atmospheric Administration (NOAA, U.S.A.), which contains a 30 -arc-second grid spanning the entire region between $-180^{\circ}$ and $180^{\circ}$ longitude and between $-65^{\circ}$ and $75^{\circ}$ latitude. The data were processed to provide a complete picture of the total nighttime light intensity. This calculation eliminates interference from daylight and moonlight intensity and refers to the method reported in Chen et al. (2020a) for the selection of cities in Jixi and Hegang by adopting the invariant area method for lighting calibration. Finally, the total nighttime light intensity data for 287 prefecture-level cities (from 1998 to 2016) were compiled using ArcGIS. The calculation index was the total annual nighttime light intensity.

Second, we compiled meteorological and pollution data. Air pollution data were derived from Columbia University's publicly available data on $\mathrm{PM}_{2.5}$ at the local city level. As the new Ambient Air Quality Standard was officially implemented in 2012, China has only recently included $\mathrm{PM}_{2.5}$ as a statistical indicator, such that all prefecture-level cities are not covered until 2015. Therefore, we adopted $\mathrm{PM}_{2.5}$ data for the period from 1998-2016 published by Columbia University as the main parameter. In addition, 2015 was taken as an example for a comparison with data published by the Ministry of Environmental Protection. In addition, we compared the observations for 2015 with the data published by the Ministry of Environmental Protection, finding that they are similar, which indicates that the data are more robust. The calculation index was the annual average $\mathrm{PM}_{2.5}$ data.

According to Hering and Poncet (2014), the ventilation coefficient is equal to the wind speed multiplied by the height of the boundary layer. We used the ERA-Interim database from the European Centre for medium-range weather forecasts (ECMWF) to calculate the ventilation coefficient for the corresponding years at a $0.75^{\circ} \times 0.75^{\circ}$ global grid of wind speed and boundary height data that span a distance of $10 \mathrm{~m}$ using ArcGIS to match the data to each city level.

Third, we constructed basic data at the city and industry levels obtained from the Statistical Almanac of Cities, State Intellectual Property Office, and provincial and municipal governments. The period spans from 1998-2016, and a series of control variables were selected, including the registered unemployed population, total population, paved road area per citizen, and number of operating buses at the end of the year. In addition, technological progress and innovation were also taken into account. Missing values in the data were interpolated via multiple interpolation to fill in the gaps with strong and stable data. For the above data, Table 1 lists the basic information and descriptive statistics of the calculated indicators while Table 2 lists the references and selection of variables. 
Table 1. Basic data and descriptive statistics

\begin{tabular}{|c|c|c|c|c|c|c|c|c|}
\hline 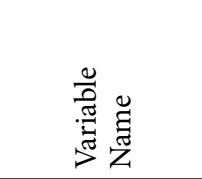 & 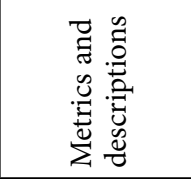 & 节 & 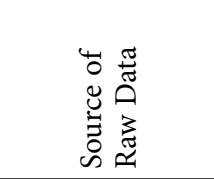 & 藏 & 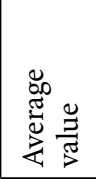 & 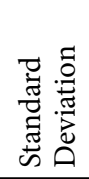 & 禀 & 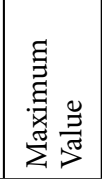 \\
\hline $\mathrm{PM}_{2.5}$ & $\begin{array}{l}\text { Average } \\
\text { concentration } \\
\text { of } \mathrm{PM}_{2.5}\end{array}$ & $\mu \mathrm{G} / \mathrm{M}^{3}$ & $\begin{array}{l}\text { China } \\
\text { Environment } \\
\text { Statistics } \\
\text { Yearbook \& } \\
\text { Ministry of } \\
\text { Environmental } \\
\text { Protection }\end{array}$ & 5,453 & 33.42 & 16.07 & 2.02 & 90.86 \\
\hline $\begin{array}{l}\text { Economic } \\
\text { Development }\end{array}$ & $\begin{array}{l}\text { Annual sum } \\
\text { of nighttime } \\
\text { light levels }\end{array}$ & 1,000 & $\begin{array}{l}\text { NGDC Satellite } \\
\text { Data }\end{array}$ & 5,453 & 79.22 & 70.13 & 3.11 & 49.3 \\
\hline \multirow[t]{2}{*}{$\begin{array}{l}\text { Population } \\
\text { Density }\end{array}$} & $\begin{array}{l}\text { Number of } \\
\text { people per } \\
\text { unit area } \\
(\log )\end{array}$ & $\begin{array}{l}\text { Person/ } \\
\mathrm{Km}^{2}\end{array}$ & $\begin{array}{l}\text { Statistical } \\
\text { Yearbook of } \\
\text { Chinese Cities }\end{array}$ & 5,453 & 6.38 & 1.05 & 3.72 & 8.38 \\
\hline & $\begin{array}{l}\text { Road area } \\
\text { per capita }\end{array}$ & Person/M $\mathrm{M}^{2}$ & $\begin{array}{l}\text { Statistical } \\
\text { Yearbook of } \\
\text { Chinese Cities }\end{array}$ & 5,453 & 16.95 & 37.73 & 0.9 & 250.46 \\
\hline \multirow[t]{2}{*}{ Infrastructure } & $\begin{array}{l}\text { Number of } \\
\text { operating } \\
\text { buses at the } \\
\text { end of the } \\
\text { year (log) }\end{array}$ & Vehicle & $\begin{array}{l}\text { Statistical } \\
\text { Yearbook of } \\
\text { Chinese Cities }\end{array}$ & 5,453 & 6.00 & 1.52 & 2.08 & 10.41 \\
\hline & $\begin{array}{l}\text { Number of } \\
\text { Hospitals } \\
(\log )\end{array}$ & Individual & $\begin{array}{l}\text { Statistical } \\
\text { Yearbook of } \\
\text { Chinese Cities }\end{array}$ & 5,453 & 5.14 & 0.75 & 1.61 & 8.02 \\
\hline \multirow[b]{2}{*}{ Public Services } & $\begin{array}{l}\text { Number of } \\
\text { Doctors (log) }\end{array}$ & Individual & $\begin{array}{l}\text { Statistical } \\
\text { Yearbook of } \\
\text { Chinese Cities }\end{array}$ & 5,453 & 8.60 & 0.77 & 6.89 & 10.69 \\
\hline & $\begin{array}{l}\text { Number of } \\
\text { universities, } \\
\text { elementary, } \\
\text { and } \\
\text { secondary } \\
\text { schools }\end{array}$ & Individual & $\begin{array}{l}\text { Statistical } \\
\text { Yearbook of } \\
\text { Chinese Cities }\end{array}$ & 5,453 & 1307.84 & 997.33 & 76 & 4,999 \\
\hline $\begin{array}{l}\text { Human } \\
\text { Capital }\end{array}$ & $\begin{array}{l}\text { Sum of } \\
\text { years of } \\
\text { education of } \\
\text { the number } \\
\text { of students } \\
\text { enrolled in } \\
\text { the region } \\
\end{array}$ & $\begin{array}{l}\text { Ten } \\
\text { Thousand } \\
\text { Years }\end{array}$ & $\begin{array}{l}\text { Statistical } \\
\text { Yearbook of } \\
\text { Chinese Cities }\end{array}$ & 5,453 & 586.22 & 473.8 & 14.31 & $5,245.94$ \\
\hline \multirow{2}{*}{$\begin{array}{l}\text { Physical } \\
\text { Capital }\end{array}$} & $\begin{array}{l}\text { Number of } \\
\text { industrial } \\
\text { enterprises } \\
\text { above scale }\end{array}$ & $\begin{array}{l}\text { Individual } \\
(100)\end{array}$ & $\begin{array}{l}\text { Statistical } \\
\text { Yearbook of } \\
\text { Chinese Cities }\end{array}$ & 5,453 & 10.24 & 15.04 & 0.19 & 187.92 \\
\hline & Acreage & $\mathrm{Km}^{2}$ & $\begin{array}{l}\text { Statistical } \\
\text { Yearbook of } \\
\text { Chinese Cities }\end{array}$ & 5,453 & 191.03 & 226.23 & 2.26 & 1,197 \\
\hline
\end{tabular}


End of Table 1

\begin{tabular}{|c|c|c|c|c|c|c|c|c|}
\hline 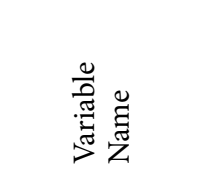 & 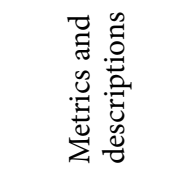 & 寻 & 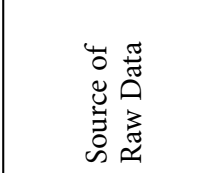 & 䒕 & 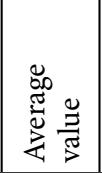 & 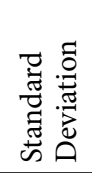 & 声罜导 & 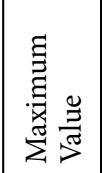 \\
\hline $\begin{array}{l}\text { Industrializa- } \\
\text { tion }\end{array}$ & $\begin{array}{l}\text { Percentage } \\
\text { of GDP of } \\
\text { secondary } \\
\text { industry }\end{array}$ & $\%$ & $\begin{array}{l}\text { Statistical } \\
\text { Yearbook of } \\
\text { Chinese Cities }\end{array}$ & 5,453 & 46.48 & 13.64 & 11.55 & 77 \\
\hline Urbanization & $\begin{array}{l}\text { Non- } \\
\text { agricultural } \\
\text { population as } \\
\text { a percentage } \\
\text { of total } \\
\text { population }\end{array}$ & $\%$ & $\begin{array}{l}\text { Statistical } \\
\text { Yearbook of } \\
\text { Chinese Cities }\end{array}$ & 5,453 & 31.96 & 16.9 & 10.37 & 85.76 \\
\hline $\begin{array}{l}\text { Environmental } \\
\text { Governance }\end{array}$ & $\begin{array}{l}\text { Government } \\
\text { reports en- } \\
\text { vironmental } \\
\text { governance } \\
\text { glossary }\end{array}$ & 1 & $\begin{array}{l}\text { Government } \\
\text { Work Report }\end{array}$ & 5,453 & 9.50 & 1.79 & 1 & 14 \\
\hline $\begin{array}{l}\text { Technological } \\
\text { Advances }\end{array}$ & $\begin{array}{l}\text { Number } \\
\text { of patent } \\
\text { applications } \\
\text { in prefecture- } \\
\text { level cities } \\
\text { (log) }\end{array}$ & Individual & \begin{tabular}{|l} 
State \\
Intellectual \\
Property Office
\end{tabular} & 5,453 & 5.89 & 1.94 & 1.79 & 10.71 \\
\hline $\begin{array}{l}\text { Air Flow } \\
\text { Coefficient }\end{array}$ & $\begin{array}{l}\text { Air flow } \\
\text { coefficient }\end{array}$ & 1 & $\begin{array}{l}\text { ERA-Interim } \\
\text { database of } \\
\text { the European } \\
\text { Centre for } \\
\text { Medium- } \\
\text { Range Weather } \\
\text { Forecasts } \\
\text { (ECMWF) }\end{array}$ & 5,453 & 2035.59 & 929.51 & 72.63 & $8,974.98$ \\
\hline
\end{tabular}

Table 2. Variable selection reference

\begin{tabular}{|l|l|}
\hline \multicolumn{1}{|c|}{ Selected Variable Indicators } & \multicolumn{1}{c|}{ Bibliography } \\
\hline Population density & Yan et al., 2020; Xu et al., 2019; Zhao \& Yuan, 2020 \\
\hline Road area per capita & Liu et al., 2019; Wang et al., 2019 \\
\hline Number of bus operations & Yan et al., 2020; Chen et al., 2020b \\
\hline Secondary industry ratio & Yan et al., 2020; Xu et al., 2019 \\
\hline Non-agricultural population ratio & Ouyang et al., 2019; Wu et al., 2020 \\
\hline $\begin{array}{l}\text { Government reports, environmental } \\
\text { governance word frequency }\end{array}$ & Chen et al., 2018 \\
\hline Number of industrial enterprises above scale & Peng, 2020; Hao, 2018 \\
\hline Number of patent applications & Ouyang, 2019; Wang \& Komonpipat, 2020 \\
\hline Human capital & Wosiek, 2020 \\
\hline Air flow coefficient & Broner et al., 2012 \\
\hline
\end{tabular}




\subsection{Model setting}

This study empirically analyzed the impact that air pollution has on economic development using data from 287 cities at prefecture-level and above in China from 1998 to 2016; we then examined government environmental regulations to further evaluate implementations of governmental sustainable development strategies and their impact on economic development. To investigate the impact that air pollution has on China's economic development, the following benchmark regression model was built based on the model of Zhao and Yuan (2020):

$$
\operatorname{DMSP}_{i t}=\alpha_{0}+\alpha_{1} \mathrm{PM}_{2 .} 5_{i t}+\alpha_{2} \mathrm{CITY}_{i t}+\eta_{c}+\delta_{t}+\varepsilon_{i t} .
$$

The average $\mathrm{PM}_{2.5}$ concentration of city I in year $\mathrm{T}$ was used to measure the air pollution. The coefficient indicates the impact that air pollution has on the economic development of the city and is therefore the core parameter of interest in this study. CITY it represents the characteristic variables of city I in year T. If $\alpha_{1}$ remains significantly negative after controlling a series of city characteristics, this indicates that air pollution will reduce economic development. In addition, there are individual and time point fixed effects, which further mitigate omitted variable bias by controlling the individual $\left(\eta_{c}\right)$ and time point effects $\left(\delta_{t}\right)$ as on overlay of the base model. Finally, we obtained the error term $\left(\varepsilon_{i t}\right)$. Unlike Zhao and Yuan (2020), the proxies selected in this study (for economic development) are nighttime light data, which further eliminate possible bias due to data collection statistics and yields a more convincing model.

Similar to previous studies (Yan et al., 2020; Ouyang et al., 2019; Liu et al., 2019; Xu et al., 2019; Wang \& Komonpipat, 2020), this study also compensated for a set of urban fixed effects variables in the benchmark regression model to minimize bias caused by the omitted variables. Specifically, the population density variable was measured by the number of people per unit area; the infrastructure variable was measured by the number of paved roads per capita, the number of operating buses at the end of the year, and the number of hospitals; the local STI (science, technology, and innovation) development variable was measured by the number of patent applications; and the urbanization variable was measured by the proportion of the urban population.

To verify the environmental Kuznets effect, we added the quadratic term for $\mathrm{PM}_{2.5}$ into Eq. (1) as follows:

$$
\operatorname{DMSP}_{i t}=\alpha_{0}+\alpha_{1} \mathrm{PM}_{2.5_{i t}}+\alpha_{2} \mathrm{PM}_{2.5^{2}}{ }_{i t}+\alpha_{3} \mathrm{CITY}_{i t}+\eta_{c}+\delta_{t}+\varepsilon_{i t} .
$$

When analyzing the impact that air pollution has on economic development based on the above benchmark model, the endogeneity of the air pollution variables becomes an issue that must be discussed. Specifically, environmental pollution may slow down economic development by decelerating urbanization and damaging human and physical capital accumulation channels. In contrast, economic development itself may affect environmental pollution through scale, technology, and structure effects. Based on the method of Hering and Poncet (2014), we selected air flow coefficient as an instrumental variable for regression.

In summary, to quantitatively investigate the impact that government environmental regulations have on smog reduction in China and its economic development, the two-stage least squares regression model (2SLS) was set up as follows: 


$$
\begin{aligned}
& \text { PM2.5 } 5_{i t}=\alpha_{0}+\alpha_{1} \mathrm{AIR}_{i t}+\alpha_{2} \mathrm{CITY}_{i t}+\beta_{1} \mathrm{GR}_{i t}+\eta_{c}+\gamma_{t}+\xi_{i t} ; \\
& \mathrm{DMSP}_{i t}=\beta_{0}+\beta_{1} \mathrm{PM}_{2} .5_{i t}+\beta_{2} \mathrm{CITY}_{i t}+\eta_{c}+\gamma_{t}+\varepsilon_{i t},
\end{aligned}
$$

where air represents the air flow coefficient, PM2.5 $5_{i t}$ represents the air pollution, DMSP ${ }_{i t}$ represents the economic growth, $\eta_{c}$ and $\gamma_{t}$ are an individual fixed effect and point-in-time fixed effect, respectively, city is an urban control variable, $\mathrm{GR}_{i t}$ is a government work report environment-related word frequency instrumental variable, and $\xi_{i t}$ is a residual.

\section{Results and analysis}

\subsection{Baseline regression results}

Table 3 lists the baseline regression results. Columns 1-3 are the regressions of the nighttime light data using $\mathrm{PM}_{2.5}$ after controlling for the control variables and fixed effects while columns 1 and 2 consider the impact that the environment has on the economy arising from public services and technological progress, respectively. Columns 4-6 account for the Kuznets effect that air pollution has on the economy, which add the squared term of $\mathrm{PM}_{2.5}$ to the basic regression. Similarly, columns 4 and 5 consider the impact that the environment has on the economy from public services and technological progress perspectives, respectively, and column 6 combines the two to consider the impact of air pollution on the economy.

Based on the results of columns 1-3 in Table 3, the effect that $\mathrm{PM}_{2.5}$ has on the economic development of a city is significantly positive, controlling for individual fixed effects and point-in-time fixed effects. According to Goodness and Prosper (2017), this may be because air pollution itself is caused by the use of natural material capital, which leads to environmental destruction. This refers to improving the economy at the expense of the environment. This result is consistent with Xie et al. (2019). With the addition of the quadratic term, the results of columns 4-6 in Table 3 show that the quadratic term is significantly negative at the $10 \%$ level, which is consistent with the Kuznets inverted U-shaped hypothesis, confirming the findings of Zhao and Yuan (2020), Zeng et al. (2019), and other studies.

Based on a combination of columns 1 and 4 in Table 3, the effect of the impact coefficient of public services on economic development is significantly positive, and the positive effect is further strengthened after the addition of the $\mathrm{PM}_{2.5}$ quadratic term, indicating that public services can promote economic development, especially for developing countries, which is also mentioned in Ouyang et al. (2019). Based on the results of columns 2 and 5 in Table 3, the effect of the coefficient of technological progress on economic development is significantly positive, indicating that technological progress has a substantial promoting effect on economic development, which is consistent with the findings of Xu et al. (2020). Based on the results of columns 3 and 6 in Table 3, after adding the two variables for technological progress and public service, the positive effects are enhanced, indicating that these variables have mutual promoting effects on economic development. The comprehensive results in columns 1-6 in Table 3 show that the impact that the infrastructure has on economic development is significantly positive, but the significance declines slightly after the addition of the technological progress factor. This may be because technological progress will promote the renewal of infrastructure, and new infrastructure has a certain lag effect on economic development. 
Table 3. Baseline regression results for air pollution and its effect on economic development

\begin{tabular}{|c|c|c|c|c|c|c|}
\hline \multicolumn{7}{|c|}{ Core explained variable: average nighttime light intensity for prefecture-level cities } \\
\hline & 1 & 2 & 3 & 4 & 5 & 6 \\
\hline $\mathrm{PM}_{2.5}$ & $\begin{array}{l}0.331^{* * *} \\
{[0.0605]}\end{array}$ & $\begin{array}{l}0.213^{* * *} \\
{[0.0453]}\end{array}$ & $\begin{array}{l}0.187^{* * *} \\
{[0.0490]}\end{array}$ & $\begin{array}{l}0.483^{* * *} \\
{[0.0014]}\end{array}$ & $\begin{array}{l}0.255^{\star * *} \\
{[0.1194]}\end{array}$ & $\begin{array}{c}0.205^{\star} \\
{[0.1221]}\end{array}$ \\
\hline $\mathrm{PM}_{2.5}{ }^{2}$ & & & & $\begin{array}{c}-0.0994^{* * *} \\
{[0.0295]}\end{array}$ & $\begin{array}{c}-0.0856^{* * *} \\
{[0.0300]}\end{array}$ & $\begin{array}{c}-0.0969^{* * *} \\
{[0.0279]}\end{array}$ \\
\hline Public services & $\begin{array}{l}4.719^{* * *} \\
{[0.6355]}\end{array}$ & & $\begin{array}{l}1.728^{\star * *} \\
{[0.6240]}\end{array}$ & $\begin{array}{l}4.673^{* * *} \\
{[0.6370]}\end{array}$ & & $\begin{array}{l}1.724^{* * *} \\
{[0.6236]}\end{array}$ \\
\hline $\begin{array}{l}\text { Technological } \\
\text { advances }\end{array}$ & & $\begin{array}{l}5.58^{\star * \star} \\
{[0.5031]}\end{array}$ & $\begin{array}{l}5.013^{\star * *} \\
{[0.5062]}\end{array}$ & & $\begin{array}{l}5.569^{* * *} \\
{[0.5063]}\end{array}$ & $\begin{array}{l}5.009^{* * *} \\
{[0.5090]}\end{array}$ \\
\hline Infrastructure & $\begin{array}{l}0.937^{\star * *} \\
{[0.1674]}\end{array}$ & $\begin{array}{l}0.701^{\star * *} \\
{[0.1728]}\end{array}$ & $\begin{array}{l}0.701^{\star * *} \\
{[0.1733]}\end{array}$ & $\begin{array}{l}0.939^{\star * *} \\
{[0.1677]}\end{array}$ & $\begin{array}{l}0.702^{\star * *} \\
{[0.1726]}\end{array}$ & $\begin{array}{l}0.701^{* * *} \\
{[0.1731]}\end{array}$ \\
\hline $\begin{array}{l}\text { Population } \\
\text { density }\end{array}$ & $\begin{array}{c}-2.741^{* * *} \\
{[0.5564]}\end{array}$ & $\begin{array}{c}-0.695 \\
{[0.5240]}\end{array}$ & $\begin{array}{c}-0.857 \\
{[0.5250]}\end{array}$ & $\begin{array}{c}-2.707^{\star * *} \\
{[0.5589]}\end{array}$ & $\begin{array}{c}-0.690 \\
{[0.5253]}\end{array}$ & $\begin{array}{c}-0.855 \\
{[0.5262]}\end{array}$ \\
\hline Constant term & Yes & Yes & Yes & Yes & Yes & Yes \\
\hline $\begin{array}{l}\text { Individual } \\
\text { fixed effects }\end{array}$ & Yes & Yes & Yes & Yes & Yes & Yes \\
\hline $\begin{array}{l}\text { Time-point } \\
\text { fixed effects }\end{array}$ & Yes & Yes & Yes & Yes & Yes & Yes \\
\hline $\begin{array}{l}\text { Observed } \\
\text { values }\end{array}$ & 5,453 & 5,453 & 5,453 & 5,453 & 5,453 & 5,453 \\
\hline Robust $\mathrm{R}^{2}$ & 0.4914 & 0.5738 & 0.5795 & 0.4919 & 0.5737 & 0.5794 \\
\hline
\end{tabular}

Note: ${ }^{*}$ indicates that the value is significant at the $10 \%$ level, ${ }^{* *}$ indicates that the value is significant at the $5 \%$ level, and ${ }^{* * *}$ indicates that the value is significant at the $1 \%$ level. Numbers in parentheses indicate standard deviation.

The effect that population density has on economic development is significantly positive and decreases after considering the quadratic term. According to Yan et al. (2020), an increase in the population density will have a positive impact on $\mathrm{PM}_{2.5}$, such that the effect of population density will decrease after considering the $\mathrm{PM}_{2.5}$ quadratic term.

\subsection{Instrumental variable regression results}

To alleviate the endogeneity problem in the previous benchmark regressions and enable an evaluation of the effect that government environmental regulations and their impact have on economic development, we used a 2SLS method to further estimate the effect that government environmental regulations have on air pollution reduction and their impact on economic development based on the air flow coefficient data obtained from the government work report word frequency. Table 4 lists the regression results. Hypothesis tests, including autocorrelation, cross-sectional correlation, and unit root test, were also conducted for the instrumental variable (IV) and TSLS, yielding significant results.

As China adopted a strong environmental regulatory policy in 2013, we presume that the Chinese government has realized that the stimulative effect of environmental pollution on economic development has reached a peak and will cross the inflection point to subsequently 
Table 4. Two-stage least squares (2SLS) instrumental variable method regression results

\begin{tabular}{|c|c|c|c|c|}
\hline $\begin{array}{l}\text { Phase One } \\
\text { Regression }\end{array}$ & \multicolumn{4}{|c|}{$\mathrm{PM}_{2.5}$} \\
\hline Time & $1998-2016$ & $1998-2016$ & $2013-2016$ & $2013-2016$ \\
\hline Air flow coefficient & $\begin{array}{c}-0.001308^{* * *} \\
{[0.000196]}\end{array}$ & $\begin{array}{c}-0.001302^{\star * *} \\
{[0.0001988]}\end{array}$ & $\begin{array}{c}-0.0009005^{\star * *} \\
{[0.0002848]}\end{array}$ & $\begin{array}{c}-0.0009977^{* * *} \\
{[0.0002862]}\end{array}$ \\
\hline $\mathrm{GR}_{i t}$ & & $\begin{array}{c}-0.001752^{\star *} \\
{[0.0007144]}\end{array}$ & & $\begin{array}{l}-1.82^{\star * *} \\
{[0.5234]}\end{array}$ \\
\hline F-value & 44.54 & 22.83 & 10.00 & 10.77 \\
\hline Two-stage regression & \multicolumn{4}{|c|}{ Nightlight The average nightlight intensity of a local city } \\
\hline $\mathrm{PM}_{2.5}$ & $\begin{array}{l}0.937^{* * *} \\
{[0.2686]}\end{array}$ & $\begin{array}{l}0.979^{\star * *} \\
{[0.2469]}\end{array}$ & $\begin{array}{c}-0.577^{\star * *} \\
{[0.2123]}\end{array}$ & $\begin{array}{c}-0.458^{\star * *} \\
{[0.1445]}\end{array}$ \\
\hline Constant term & Yes & Yes & Yes & Yes \\
\hline Control variables & Yes & Yes & Yes & Yes \\
\hline $\begin{array}{l}\text { Individual fixed } \\
\text { effects }\end{array}$ & Yes & Yes & Yes & Yes \\
\hline $\begin{array}{l}\text { Time-point fixed } \\
\text { effects }\end{array}$ & Yes & Yes & Yes & Yes \\
\hline Observed Values & 5,388 & 5,388 & 1,136 & 1,136 \\
\hline Robust $\left(\mathrm{R}^{2}\right)$ & 0.4362 & 0.4224 & 0.5950 & 0.6077 \\
\hline
\end{tabular}

Note: ${ }^{*}$ indicates that the value is significant at the $10 \%$ level, ${ }^{* *}$ indicates that the value is significant at the $5 \%$ level, and ${ }^{* * *}$ indicates that the value is significant at the $1 \%$ level. Numbers in parentheses indicate standard deviation.

have a restraining effect. In view of this prediction, 2013 was selected as the cut-off point for verification, and we assumed that environmental pollution had an inhibiting effect on economic development after 2013, which is consistent with the hypothesis. We can observe that the government's environmental policies all reduce smog pollution at the $1 \%$ significance level. At the same time, to address the possible endogeneity problem in the "two-way causality", we performed an instrumental regression with a lag in the $\mathrm{PM}_{2.5}$ by 1-2 periods; we can observe that the results are consistently robust. The results listed in Table 4 are similar to the baseline regressions reported in Table 3, proving that air pollution has a positive impact on economic development, as observed for the period from 1998-2016. However, the positive impact is gradually weakening because the main cause of air pollution is the use of environmental resources for development. Columns 3-4 indicate that since 2013, air pollution has had a negative impact on the economy, which shows that China has already crossed the inflection point in the inverted U-shaped Kuznets curve, rendering air pollution to have an inhibiting effect on the economy. At the same time, if not controlled, environmental pollution in China will have an impact on the economy after a certain period. The recession has reached its peak and has begun to accelerate. Furthermore, we selected representative cities in the Beijing-Tianjin-Hebei, Yangtze River Delta, and Pearl River Delta regions for visualization according to the "Ten Articles of the Atmosphere", as shown in Figure 1. Based on Figure 1, the overall $\mathrm{PM}_{2.5}$ value has been fluctuating and decreasing since 2005, especially since the promulgation of the "Ten Articles of the Atmosphere" in 2013, with a significant decrease in the $\mathrm{PM}_{2.5}$ concentration in 2014. 

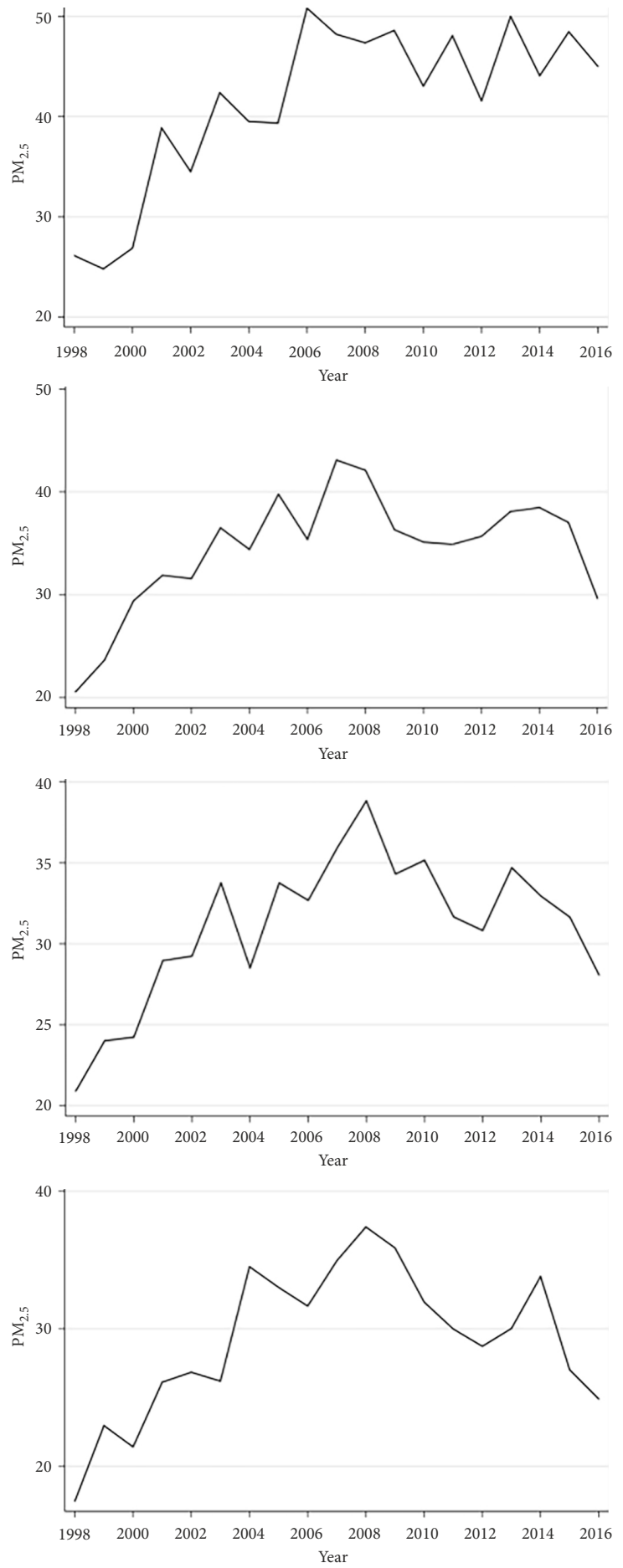

Figure 1. $\mathrm{PM}_{2.5}$ trends in representative cities of Beijing-Tianjin-Hebei, Yangtze River Delta, and Pearl River Delta Region 
Based on the above results, we can observe that air pollution in the sample period has significantly increased China's economic development, but the effect is gradually decreasing. The government has an irreplaceable role in the process of air pollution control. In other words, the government can take proactive and effective measures to simultaneously mitigate air pollution and promote economic development.

\subsection{Robustness test}

To ensure the validity of the instrumental variables in Table 4 and the reliability of our conclusions, we performed a series of robustness checks on the regressions in Table 5 using the GDP.

As nighttime lighting is highly correlated with the GDP, the results are robust if the regressions with alternative indicators yield similar results. To yield more convincing results, we excluded four municipalities (Beijing, Tianjin, Shanghai, and Chongqing) and three groups of less developed regions (Tongren, Bijie, and Haidong) from the regressions. The results are reported in Table 5.

Table 5. Results of two-stage least squares (2SLS) instrumental variable method robustness tests

\begin{tabular}{|c|c|c|c|c|c|c|}
\hline $\begin{array}{l}\text { Phase One } \\
\text { Regression }\end{array}$ & \multicolumn{6}{|c|}{$\mathrm{PM}_{2.5}$} \\
\hline Sample & \multicolumn{2}{|c|}{ Full Sample } & \multirow{2}{*}{$\begin{array}{c}\begin{array}{c}\text { Robust } \\
\text { Sample }\end{array} \\
1998-2016\end{array}$} & \multicolumn{2}{|c|}{ Full Sample } & \multirow{2}{*}{$\begin{array}{c}\begin{array}{c}\text { Robust } \\
\text { Sample }\end{array} \\
2013-2016\end{array}$} \\
\hline Time & $1998-2016$ & $1998-2016$ & & $2013-2016$ & $2013-2016$ & \\
\hline $\begin{array}{l}\text { Air flow } \\
\text { coefficient }\end{array}$ & $\begin{array}{c}-0.001282^{\star * *} \\
{[0.0002125]}\end{array}$ & $\begin{array}{c}-0.001229^{* * *} \\
{[0.0001989]}\end{array}$ & $\begin{array}{c}-0.001133^{\star * *} \\
{[0.0001848]}\end{array}$ & $\begin{array}{c}-0.001612^{\star * *} \\
{[0.0003061]}\end{array}$ & $\begin{array}{c}-0.001711^{\star * *} \\
{[0.0003071]}\end{array}$ & $\begin{array}{c}-0.001663^{\star * *} \\
{[0.0003144]}\end{array}$ \\
\hline $\mathrm{GR}_{i t}$ & & $\begin{array}{l}-3.579^{\star *} \\
{[0.4509]}\end{array}$ & $\begin{array}{c}-2.693^{\star * *} \\
{[0.4568]}\end{array}$ & & $\begin{array}{l}-1.481^{\star *} \\
{[0.6083]}\end{array}$ & $\begin{array}{l}-2.48^{\star *} \\
{[0.6405]}\end{array}$ \\
\hline F-value & 36.42 & 42.39 & 31.37 & 27.73 & 17.08 & 19.2 \\
\hline $\begin{array}{l}\text { Two-stage } \\
\text { regression }\end{array}$ & \multicolumn{6}{|c|}{ GDP } \\
\hline $\mathrm{PM}_{2.5}$ & $\begin{array}{l}40.38^{\star \star} \\
{[19.72]} \\
\end{array}$ & $\begin{array}{l}79.09^{* * *} \\
{[11.08]}\end{array}$ & $\begin{array}{c}74.69^{* * *} \\
{[13.71]}\end{array}$ & $\begin{array}{c}-66.61^{* * *} \\
{[17.93]}\end{array}$ & $\begin{array}{c}-48.78^{\star \star *} \\
{[12.42]}\end{array}$ & $\begin{array}{c}-41.64^{* * *} \\
{[12.76]}\end{array}$ \\
\hline $\begin{array}{l}\text { Constant } \\
\text { term }\end{array}$ & Yes & Yes & Yes & Yes & Yes & Yes \\
\hline $\begin{array}{l}\text { Control } \\
\text { variables }\end{array}$ & Yes & Yes & Yes & Yes & Yes & Yes \\
\hline $\begin{array}{l}\text { Individual } \\
\text { fixed effects }\end{array}$ & Yes & Yes & Yes & Yes & Yes & Yes \\
\hline $\begin{array}{l}\text { Time-point } \\
\text { fixed effects }\end{array}$ & Yes & Yes & Yes & Yes & Yes & Yes \\
\hline $\begin{array}{l}\text { Observed } \\
\text { values }\end{array}$ & 5,388 & 5,388 & 5,312 & 1,136 & 1,136 & 1,120 \\
\hline Robust $\left(\mathrm{R}^{2}\right)$ & 0.7857 & 0.7104 & 0.6432 & 0.3182 & 0.3326 & 0.2550 \\
\hline
\end{tabular}

Note: ${ }^{*}$ indicates that the value is significant at the $10 \%$ level, ${ }^{* *}$ indicates that the value is significant at the $5 \%$ level, and ${ }^{* * *}$ indicates that the value is significant at the $1 \%$ level. Numbers in parentheses indicate standard deviation. 


\subsection{Transmission mechanism hypothesis}

Furthermore, to investigate the specific transmission mechanism of air pollution with respect to economic development, we proposed two hypotheses to investigate both human capital and physical capital.

Hypothesis 1: The impact that air pollution has on the economy through physical capital requires a comprehensive consideration of both the positive and negative effects.

Air pollution can reduce the quality of economic development by destroying the urbanization process and slowing down the rate of physical capital accumulation. In contrast, most causes of air pollution occur through the use of natural physical capital for industrial scale production, which increases the access to and utilization of natural physical capital, thus partially promoting economic development. The impact on physical capital is mainly due to the combined positive and negative impacts of these two factors.

Hypothesis 2: Air pollution affects the economy through human capital, which mainly affects the economic development by influencing human capital accumulation and personal health.

In terms of human capital, air pollution reduces the accumulation of urban talent by decreasing the livability of the city and decelerating the urbanization process, which in turn reduces human capital. At the same time, air pollution may affect the accumulation of human capital by affecting individual and lifespans and health, thus reducing human capital.

Based on these hypotheses, the total number of years of education in the city was selected as a proxy for human capital, the number of industrial enterprises and the area of cultivated land were selected as proxies for physical capital accumulation, and the percentage of the non-farm population was selected as a proxy for the urbanization process. Tables 6 and 7 lists the regression results.

Table 6. Regression results for physical capital

\begin{tabular}{|l|c|l|c|}
\hline \multicolumn{2}{|c|}{$\begin{array}{c}\text { Impact of physical capital on economic } \\
\text { development }\end{array}$} & \multicolumn{2}{c|}{$\begin{array}{c}\text { Impact of } \mathrm{PM}_{2.5} \text { on physical capital } \\
\text { accumulation }\end{array}$} \\
\hline & Nightlight & & Physical Capital \\
\hline Physical capital & $0.253^{* * *}$ & $\mathrm{PM}_{2.5}$ & $\begin{array}{c}-0.730^{* * *} \\
{[0.0717]}\end{array}$ \\
\hline Control variables & Yes & Control variables & Yes \\
\hline Constant term & Yes & Constant term & Yes \\
\hline Individual fixed effects & Yes & Individual fixed effects & Yes \\
\hline Time-point fixed effects & Yes & Time-point fixed effects & Yes \\
\hline Observed values & 5,396 & Observed Values & 5,396 \\
\hline Robust $\left(\mathrm{R}^{2}\right)$ & 0.5367 & Robust $\mathrm{R}^{2}$ & 0.1920 \\
\hline
\end{tabular}

Note: ${ }^{*}$ indicates that the value is significant at the $10 \%$ level, ${ }^{* *}$ indicates that the value is significant at the $5 \%$ level, and ${ }^{* *}$ indicates that the value is significant at the $1 \%$ level. Numbers in parentheses indicate standard deviation. 
Table 7. Regression results for human capital

\begin{tabular}{|l|c|l|c|}
\hline \multicolumn{2}{|c|}{$\begin{array}{c}\text { Impact of human capital on economic } \\
\text { development }\end{array}$} & \multicolumn{2}{c|}{$\begin{array}{c}\text { Impact of } \mathrm{PM}_{2.5} \text { on human } \\
\text { capital accumulation }\end{array}$} \\
\hline & Nightlight & & Human Capital \\
\hline Human Capital & $\begin{array}{c}0.0247^{* * *} \\
{[0.0028]}\end{array}$ & $\mathrm{PM}_{2.5}$ & $\begin{array}{c}-12.51^{* * *} \\
{[2.9099]}\end{array}$ \\
\hline Control variables & Yes & Control variables & Yes \\
\hline Constant term & Yes & Constant term & Yes \\
\hline Individual fixed effects & Yes & Individual fixed effects & Yes \\
\hline Time-point fixed effects & Yes & Time-point fixed effects & Yes \\
\hline Observed values & 5,453 & Observed Values & 5,453 \\
\hline Robust $\left(\mathrm{R}^{2}\right)$ & 0.6101 & Robust $\mathrm{R}^{2}$ & 0.4573 \\
\hline
\end{tabular}

Note: ${ }^{*}$ indicates that the value is significant at the $10 \%$ level, ${ }^{* *}$ indicates that the value is significant at the $5 \%$ level, and ${ }^{* * *}$ indicates that the value is significant at the $1 \%$ level. Numbers in parentheses indicate standard deviation.

\subsection{Validation of regression results with transmission mechanism hypothesis}

Based on the regression results in Tables 6 and 7, the transmission mechanisms of physical capital and human capital are sufficiently verified. The signs of the coefficients are consistent with expectations and are significant at the $1 \%$ confidence level. However, according to Hypothesis 1, under the hedge of the positive and negative effects of physical capital on the economy, air pollution will eventually have a negative effect on physical capital. The negative effect of air pollution on human capital in Hypothesis 2 has also been confirmed, which is also consistent with people's intuitive perception of facts.

\subsection{Heterogeneity analysis}

The regressions of the instrumental variables in the preceding sections show that the overall impact of air pollution on economic growth is positive; however, the sub regressions in Table 3 (columns 13-16) show that the impact of air pollution on economic growth is negative when the endogenous driving force of China's economic growth shifts from natural resource extraction to R\&D and technological innovation. This is one of the main reasons why China must combat air pollution if it wishes to achieve high-quality economic development. To explore the key nodes of China's economic transition, we conducted a regression on time heterogeneity, whose results are listed in Table 8. To investigate the impact that air pollution has on cities of different sizes, we used the resident population to classify cities according to the 2014 version of the city size standard and performed a heterogeneity analysis, whose results are listed in Table 9.

Based on Table 8, at the 1\% significance level, 2011 was significantly positive and 2012 was significantly negative; therefore, the transformation of China's economic endogenous power should have occurred between 2011 and 2012. In 2010, China's frequent extreme high temperature, heavy rain events caused air pollution had a negative effect on economic growth. 
Table 8. Results of the time heterogeneity of air pollution and economic growth

\begin{tabular}{|c|c|c|c|c|}
\hline $\begin{array}{l}\text { Phase One } \\
\text { Regression }\end{array}$ & \multicolumn{4}{|c|}{$\mathrm{PM}_{2.5}$} \\
\hline Start time & 2010 & 2011 & 2012 & 2013 \\
\hline Air flow coefficient & $\begin{array}{c}-0.001204^{* * *} \\
{[0.0001836]}\end{array}$ & $\begin{array}{c}-0.001202^{\star * *} \\
{[0.000212]}\end{array}$ & $\begin{array}{c}-0.001936^{\star * *} \\
{[0.0003161]}\end{array}$ & $\begin{array}{c}-0.001244^{* * *} \\
{[0.0002966]}\end{array}$ \\
\hline F-value & 42.99 & 32.11 & 37.49 & 17.58 \\
\hline Two-stage regression & \multicolumn{4}{|c|}{ Nightlight The average nightlight intensity of a local city. } \\
\hline $\mathrm{PM}_{2.5}$ & $\begin{array}{r}-0.07506 \\
{[0.7768]}\end{array}$ & $\begin{array}{l}0.05515 \\
{[1.014]}\end{array}$ & $\begin{array}{l}-0.1164^{*} \\
{[0.6641]}\end{array}$ & $\begin{array}{c}-0.5070^{* * *} \\
{[0.1418]}\end{array}$ \\
\hline Constant term & Yes & Yes & Yes & Yes \\
\hline Control variables & Yes & Yes & Yes & Yes \\
\hline $\begin{array}{l}\text { Individual fixed } \\
\text { effects }\end{array}$ & Yes & Yes & Yes & Yes \\
\hline $\begin{array}{l}\text { Time-point fixed } \\
\text { effects }\end{array}$ & Yes & Yes & Yes & Yes \\
\hline Observed values & 1,988 & 1,704 & 1,420 & 1,136 \\
\hline Robust $\left(\mathrm{R}^{2}\right)$ & 0.2467 & 0.2275 & 0.0923 & 0.5937 \\
\hline
\end{tabular}

Note: ${ }^{*}$ indicates that the value is significant at the $10 \%$ level, ${ }^{* *}$ indicates that the value is significant at the $5 \%$ level, and ${ }^{* * *}$ indicates that the value is significant at the $1 \%$ level. Numbers in parentheses indicate standard deviation.

Table 9. Individual heterogeneity results for air pollution and economic growth

\begin{tabular}{|l|c|c|c|c|}
\hline Phase One Regression & \multicolumn{4}{|c|}{$\mathrm{PM}_{2.5}$} \\
\hline City features & Full Sample & $\begin{array}{c}\text { Jumbo and Mega } \\
\text { Cities }\end{array}$ & Big Cities & $\begin{array}{c}\text { Small and } \\
\text { Medium Cities }\end{array}$ \\
\hline Air flow Coefficient & $\begin{array}{c}-0.001243^{* * *} \\
{[0.0002035]}\end{array}$ & $\begin{array}{c}-0.002247^{* * *} \\
{[0.0004002]}\end{array}$ & $\begin{array}{c}-0.0009413^{* * *} \\
{[0.0002304]}\end{array}$ & $\begin{array}{c}0.002007 \\
{[0.0006173]}\end{array}$ \\
\hline F-value & 37.35 & 31.53 & 16.69 & 0.11 \\
\hline Two-stage regression & \multicolumn{4}{|c|}{ Nightlight The average nightlight intensity of a local city. } \\
\hline PM $_{2.5}$ & $0.8904^{* * *}$ & 0.4539 & $1.097^{* * *}$ & -2.663 \\
{$[0.3054]$} & {$[0.3322]$} & {$[0.4045]$} & {$[0.9247]$} \\
\hline Constant term & Yes & Yes & Yes & Yes \\
\hline Control variables & Yes & Yes & Yes & Yes \\
\hline Individual fixed effects & Yes & Yes & Yes & Yes \\
\hline Time-point fixed effects & Yes & Yes & Yes & Yes \\
\hline Observed values & 5,388 & 1,683 & 3,469 & 236 \\
\hline Robust $\left(\mathrm{R}^{2}\right)$ & 0.5189 & 0.6127 & 0.2496 & -3.6607 \\
\hline
\end{tabular}

Note: ${ }^{*}$ indicates that the value is significant at the $10 \%$ level, ${ }^{* *}$ indicates that the value is significant at the $5 \%$ level, and ${ }^{* * *}$ indicates that the value is significant at the $1 \%$ level. Numbers in parentheses indicate standard deviation. 
Therefore, the overall regression results for 2010-2016 had no significant negative effect. Eliminating the effect after 2010, for 2011-2016, a significant positive return and significant negative abnormal return from 2012-2016 suggest that China's Kuznets turning point was between 2011-2012. At the same time, the regression results in 2013-2016 and results in Table 3 support each other. The policies and programs that have been introduced are also relevant to this hypothesis. Based on Table 9, the explanation of the full sample is more dependent on large cities. Owing to the large number of individuals, as well as to the initiation of the development of large cities, the marginal effect of large cities is significantly greater than that of megacities and small- and medium-sized cities. For megacities, their insignificant coefficients may be due to the fact that most existing megacities are municipalities directly under the central government or provincial capitals. Apart from the influence of air pollution, political choice is a highly important factor in their economic growth. As the central government and local government jointly promote the growth of cities, the explanatory power of air pollution is weak, such that the coefficient is not significant. Although Table 9 is based on the results of the entire sample, we can observe that for super-large cities, the effect that air pollution has on economic growth is significantly lower than the overall sample, which also confirms the hypothesis of the two conduction mechanism. Megacities have more of a dependence on advanced talents than big cities and small- and medium-sized cities. For small- and medium-sized cities, the sample is too small and does not pass the significance test, such that we cannot make this assertion.

\section{Conclusions and suggestions}

Air pollution and environmental crises are serious external challenges facing humanity amidst the unprecedented changes that have occurred in the past century, especially as China's development enters a new normal. We therefore face multiple questions, such as "how can we sustain high-quality economic development while safeguarding the environment?", "how can we mitigate the negative effects of air pollution and climate change through environmental management?", and "how can we achieve high-speed economic and social development with simultaneous environmental sustainability?”.

To achieve a win-win bi-directional symbiosis between the environment and economy, it is not only necessary to understand the government's macro-environmental policies, but also to evaluate and revise the government's public policies in a precise and scientific manner.

Based on this study, the impact that air pollution has on the economy follows the Kuznets environmental curve; according to the existing sample data, air pollution still plays a role in promoting the economy. However, since 2012, China's economy has entered a new normal; as air pollution has an inhibiting effect on the economy, the country has increased environmental regulations since 2013 to achieve high-quality economic development. The impact of air pollution on the economy is based on both physical and human capital while technological progress is a catalyst for environmental management. Based on our findings and the validated hypothesis, the government can implement the following measures: 1) reduce air pollution by increasing technological investment and promoting industrial upgrades and transformation; and 2) increase the green area in cities through afforestation and reduce urban core area pollution to attract talent, enhance human capital, and promote innovation. 
Through data research, we can observe that the consequence of economic development at all costs (after reform) is that environmental pressures and air pollution are increasing continuously and will have a negative impact on economic development, leading to a gradual decline in the level and speed of economic development. The only path to manage such a dilemma is to break the air pollution cycle. Only through scientific and reasonable public environmental policies can we change the nature of this situation. Implementing sustainable development, practicing "green, open, and sharing", optimizing and adjusting industrial structures through supply-side reform, improving governance capacity and efficiency, and building a community of human destiny will ultimately lead to the harmonious coexistence of humans and nature.

\section{Disclosure statement}

The authors declare that they do not they have any competing financial, professional, or personal interests.

\section{Funding}

This study was supported by the Major Program of the National Social Science Foundation of China (Grant No. 20ZDA084); the National Natural Science Foundation of China (Grant Nos. 71934001, 71471001, 41771568, and 71533004); the National Key Research and Development Program of China (Grant No. 2016YFA0602500); the Strategic Priority Research Program of the Chinese Academy of Sciences (Grant No. XDA23070400); and the Sichuan Province Social Science High Level Research Team Building.

\section{References}

Broner, F., Bustos, P., \& Carvalho, V. M. (2012). Sources of comparative advantage in polluting industries (NBER Working Paper No. 18337). National Bureau of Economic Research. https://doi.org/10.3386/w18337

Chen, J. D., Gao, M., Cheng, S., Hou, W., Song, M., Liu, X., Liu, Y., \& Shan, Y. (2020a). County-level $\mathrm{CO}_{2}$ emissions and sequestration in China during 1997-2017. Scientific Data, 7, 391. https://doi.org/10.1038/s41597-020-00736-3

Chen, J. D., Wang, B., Huang, S., \& Song, M. L. (2020b). The influence of increased population density in China on air pollution. Science of The Total Environment, 735, 139456. https://doi.org/10.1016/j.scitotenv.2020.139456

Chen, Z., Kahn, M. E., Liu, Y., \& Wang, Z. (2018). The consequences of spatially differentiated water pollution regulation in China. Journal of Environmental Economics and Management, 88, 468-485. https://doi.org/10.1016/j.jeem.2018.01.010

Dubey, R., Gunasekaran, A., Childe, S. J., Papadopoulos, T., Luo, Z. W., Wamba, S. F., \& Roubaud, D. (2019). Can big data and predictive analytics improve social and environmental sustainability? Technological Forecasting and Social Change, 144, 534-545.

https://doi.org/10.1016/j.techfore.2017.06.020 
Egbetokun, S., Osabuohien, E., Akinbobola, T., Onanuga, O. T., Gershon, O., \& Okafor, V. (2020). Environmental pollution, economic growth and institutional quality: Exploring the nexus in Nigeria. Management of Environmental Quality, 31(1), 18-31. https://doi.org/10.1108/MEQ-02-2019-0050

Fan, X. M., \& Xu, Y. Z. (2020). Convergence on the haze pollution: City-level evidence from China. Atmospheric Pollution Research, 11(6) 141-152. https://doi.org/10.1016/j.apr.2020.03.004

Gong, X. M., Zhang, J. P., Zhang, H. R., Cheng, M. W., Wang, F., \& Yu, N. (2020). Internet use encourages pro-environmental behavior: Evidence from China. Journal of Cleaner Production, 256, 120725. https://doi.org/10.1016/j.jclepro.2020.120725

Goodness, C. A., \& Prosper, E. E. (2017). Effect of economic growth on $\mathrm{CO}_{2}$ emission in developing countries: Evidence from a dynamic panel threshold model. Cogent Economics \& Finance, 5(1), 1379239. https://doi.org/10.1080/23322039.2017.1379239

Grossman, G. M., \& Krueger, A. B. (1991). Environmental impacts of a North American free trade agreement (NBER Working Papers No. 3914). National Bureau of Economic Research.

https://doi.org/10.3386/w3914

Grossman, G. M., \& Krueger, A. B. (1995). Economic growth and the environment. The Quarterly Journal of Economics, 110(2), 353-377. https://doi.org/10.2307/2118443

Han, F., \& Li, J. M. (2020). Assessing impacts and determinants of China's environmental protection tax on improving air quality at provincial level based on Bayesian statistics. Journal of Environmental Management, 271, 111017. https://doi.org/10.1016/j.jenvman.2020.111017

Hanaoka, T., \& Masui, T. (2020). Exploring effective short-lived climate pollutant mitigation scenarios by considering synergies and trade-offs of combinations of air pollutant measures and low carbon measures towards the level of the $2{ }^{\circ} \mathrm{C}$ target in Asia. Environmental Pollution, 261, 113650. https://doi.org/10.1016/j.envpol.2019.113650

Hao, Y., Peng, H., Temulun, T., Liu, L. Q., Mao, J., Lu, Z. N., \& Chen, H. (2018). How harmful is air pollution to economic development? New evidence from $\mathrm{PM}_{2.5}$ concentrations of Chinese cities. Journal of Cleaner Production, 172, 743-757. https://doi.org/10.1016/j.jclepro.2017.10.195

He, G. Y., Chen, Y. S., Wang, S. H., Dong, Y. Q., Ju, G. D., \& Chen, B. W. (2020). The association between $\mathrm{PM}_{2.5}$ and depression in China. Dose-Response, 18(3). https://doi.org/10.1177/1559325820942699

Henderson, J. V., Storeygard, A., \& Weil, D. N. (2012). Measuring economic growth from outer space. American Economic Review, 102(2), 994-1028. https://doi.org/10.1257/aer.102.2.994

Hering, L., \& Poncet, S. (2014). Environmental policy and exports: Evidence from Chinese cities. Journal of Environmental Economics and Management, 68(2), 296-318. https://doi.org/10.1016/j.jeem.2014.06.005

Iacobuta, A. O., Mursa, G. C., Mihai, C., Cautisanu, C., \& Cismas, L. M. (2019). Institutions and sustainable development: A cross-country analysis. Transformations in Business \& Economics, 18, 628-646.

Ji, G. X., Tian, L., Zhao, J. C., Yue, Y. L., \& Wang, Z. (2019a). Detecting spatiotemporal dynamics of PM2.5 emission data in China using DMSP-OLS nighttime stable light data. Journal of Cleaner Production, 209, 363-370. https://doi.org/10.1016/j.jclepro.2018.10.285

Ji, X. L., Li, X. Z., He, Y. Q., \& Liu, X. L. (2019b). A simple method to improve estimates of county-level economics in china using nighttime light data and GDP growth rate. ISPRS International Journal of Geo-Information, 8(9), 419. https://doi.org/10.3390/ijgi8090419

Jiang, P., Yang, J., Huang, C. H., \& Liu, H. K. (2018). The contribution of socioeconomic factors to PM2.5 pollution in urban China. Environmental Pollution, 233, 977-985. https://doi.org/10.1016/j.envpol.2017.09.090

Kacprzyk, A., \& Kuchta, Z. (2020). Shining a new light on the environmental Kuznets curve for $\mathrm{CO}_{2}$ emissions. Energy Economics, 87, 104704. https://doi.org/10.1016/j.eneco.2020.104704 
Lin, B. Q., \& Jia, Z. J. (2019). What will China's carbon emission trading market affect with only electricity sector involvement? A CGE based study. Energy Economics, 78, 301-311. https://doi.org/10.1016/j.eneco.2018.11.030

Lin, F. Q. (2017). Trade openness and air pollution: City-level empirical evidence from China. China Economic Review, 45, 78-88. https://doi.org/10.1016/j.chieco.2017.07.001

Liu, Q. Q., Wang, S. J., Zhang, W. Z., Li, J. M., \& Dong, G. P. (2019). The effect of natural and anthropogenic factors on $\mathrm{PM}_{2.5}$ : Empirical evidence from Chinese cities with different income levels. Science of The Total Environment, 653, 157-167. https://doi.org/10.1016/j.scitotenv.2018.10.367

Liu, Y., \& Lu, Y. Y. (2015). The Economic impact of different carbon tax revenue recycling schemes in China: A model-based scenario analysis. Applied Energy, 141(1), 96-105. https://doi.org/10.1016/j.apenergy.2014.12.032

Ma, T., Zhou, C. H., Pei, T., Haynie, S., \& Fan, J. F. (2012). Quantitative estimation of urbanization dynamics using time series of DMSP/OLS nighttime light data: A comparative case study from China's cities. Remote Sensing of Environment, 124, 99-107. https://doi.org/10.1016/j.rse.2012.04.018

Maji, K. J., Ye, W. F., Arora, M., \& Nagendra, S. M. S. (2018). $\mathrm{PM}_{2.5}$-related health and economic loss assessment for 338 Chinese cities. Environment International, 121(1), 392-403. https://doi.org/10.1016/j.envint.2018.09.024

Masiol, M., Hopke, P. K., Felton, H. D., Frank, B. P., Rattigan, O. V., Wurth, M. J., \& LaDuke, G. H. (2017). Source apportionment of $\mathrm{PM}_{2.5}$ chemically speciated mass and particle number concentrations in New York City. Atmospheric Environment, 148, 215-229.

https://doi.org/10.1016/j.atmosenv.2016.10.044

Ouyang, X., Shao, Q. L., Zhu, X., He, Q. Y., Xiang, C., \& Wei, G. E. (2019). Environmental regulation, economic growth and air pollution: Panel threshold analysis for OECD countries. Science of The Total Environment, 657, 234-241. https://doi.org/10.1016/j.scitotenv.2018.12.056

Peng, X. (2020). Strategic interaction of environmental regulation and green productivity growth in China: Green innovation or pollution refuge? Science of The Total Environment, 732, 139200. https://doi.org/10.1016/j.scitotenv.2020.139200

Ren, L. N., \& Matsumoto, K. (2020). Effects of socioeconomic and natural factors on air pollution in China: A spatial panel data analysis. Science of The Total Environment, 740, 140155. https://doi.org/10.1016/j.scitotenv.2020.140155

Shi, T., Hu, Y., Liu, M., Li, C., Zhang, C., \& Liu, C. (2020). How do economic growth, urbanization, and industrialization affect fine particulate matter concentrations? An assessment in Liaoning Province, China. International Journal of Environmental Research and Public Health, 17(15), 5441. https://doi.org/10.3390/ijerph17155441

Song, C. B., He, J. J., Wu, L., Jin, T. S., Chen, X., Li, R. P., Ren, P. P., Zhang, L., \& Mao, H. J. (2017). Health burden attributable to ambient $\mathrm{PM}_{2.5}$ in China. Environmental Pollution, 223, 575-586. https://doi.org/10.1016/j.envpol.2017.01.060

Song, Y., Zhou, A., Zhang, M., \& Wang, H. (2019). Assessing the effects of haze pollution on subjective well-being based on Chinese General Social Survey. Journal of Cleaner Production, 235, 574-582. https://doi.org/10.1016/j.jclepro.2019.07.021

Stern, D. I., \& Zha, D. L. (2016). Economic growth and particulate pollution concentrations in China. Environmental Economics and Policy Studies, 18, 327-338. https://doi.org/10.1007/s10018-016-0148-3

Tan, X. J., Liu., Y., Cui, J. B., \& Su, B. (2018). Assessment of carbon leakage by channels: An approach combining CGE model and decomposition analysis. Energy Economics, 74, 535-545. https://doi.org/10.1016/j.eneco.2018.07.003 
Wang, S. J., Fang, C. L., Guan, X. L., Pang, B., \& Ma, H. T. (2014). Urbanisation, energy consumption, and carbon dioxide emissions in China: A panel data analysis of China's provinces. Applied Energy, 136(C), 738-749. https://doi.org/10.1016/j.apenergy.2014.09.059

Wang, S. J., Liu, X. P., Yang, X., Zou, B., \& Wang, J. Y. (2018). Spatial variations of $\mathrm{PM}_{2.5}$ in Chinese cities for the joint impacts of human activities and natural conditions: A global and local regression perspective. Journal of Cleaner Production, 203, 143-152. https://doi.org/10.1016/j.jclepro.2018.08.249

Wang, S. J., Fang, C. L., Sun, L. X., Su, Y. X., Chen, X. Z., Zhou, C. S., Feng, K. S., \& Hubacek, K. (2019). Decarbonizing China's urban agglomerations. Annals of the American Association of Geographers, 109(1), 266-285. https://doi.org/10.1080/24694452.2018.1484683

Wang, Y., \& Komonpipat, S. (2020). Revisiting the environmental Kuznets curve of $\mathrm{PM}_{2.5}$ concentration: Evidence from prefecture-level and above cities of China. Environmental Science and Pollution Research, 27, 9336-9348. https://doi.org/10.1007/s11356-020-07621-X

Wang, Y., Zhang, C., Lu, A., Li, L., He, Y., ToJo, J., \& Zhu, X. (2017). A disaggregated analysis of the environmental Kuznets curve for industrial $\mathrm{CO}_{2}$ emissions in China. Applied Energy, 190, 172-180. https://doi.org/10.1016/j.apenergy.2016.12.109

Wang, Z. L., \& Zhu, Y. F. (2020). Do energy technology innovations contribute to $\mathrm{CO}_{2}$ emissions abatement? A spatial perspective. Science of the Total Environment, 726, 138574.

https://doi.org/10.1016/j.scitotenv.2020.138574

Wolde-Rufael, Y., \& Idowu, S. (2017). Income distribution and $\mathrm{CO}_{2}$ emission: A comparative analysis for China and India. Renewable and Sustainable Energy Reviews, 74, 1336-1345. https://doi.org/10.1016/j.rser.2016.11.149

Wosiek, M. (2020). Rural?urban divide in human capital in Poland after 1988. Oeconomia Copernicana, 11(1), 183-201. https://doi.org/10.24136/oc.2020.008

Wu, H. T., Li, Y. W., Hao, Y., Ren, S. Y., \& Zhang, P. F. (2020). Environmental decentralization, local government competition, and regional green development: Evidence from China. Science of The Total Environment, 708, 135085. https://doi.org/10.1016/j.scitotenv.2019.135085

Xie, Q. C., Xu, X., \& Liu, X. Q. (2019). Is there an EKC between economic growth and smog pollution in China? New evidence from semiparametric spatial autoregressive models. Journal of Cleaner Production, 220, 873-883. https://doi.org/10.1016/j.jclepro.2019.02.166

Xu, B., Luo, LQ., \& Lin, BQ. (2016). A dynamic analysis of air pollution emissions in China: Evidence from nonparametric additive regression models. Ecological Indicators, 63, 346-358. https://doi.org/10.1016/j.ecolind.2015.11.012

Xu, G., Feng, X., Li, Y., Chen, X., \& Jia, J. (2017). Environmental risk perception and its influence on well-being. Chinese Management Studies, 11(1), 35-50. https://doi.org/10.1108/CMS-12-2016-0261

Xu, F. J., Huang, Q. X., Yue, H. B., He, C. Y., Wang, C. B., \& Zhang, H. (2020). Reexamining the relationship between urbanization and pollutant emissions in China based on the STIRPAT model. Journal of Environmental Management, 273, 111134. https://doi.org/10.1016/j.jenvman.2020.111134

Xu, S. C., Miao, Y. M., Gao, C., Long, R. Y., Chen, H., Zhao, B., \& Wang, S. X. (2019). Regional differences in impacts of economic growth and urbanization on air pollutants in China based on provincial panel estimation. Journal of Cleaner Production, 208, 340-352.

https://doi.org/10.1016/j.jclepro.2018.10.114

Yan, D., Ren, X. H., Kong, Y., Ye, B., \& Liao, Z. Y. (2020). The heterogeneous effects of socioeconomic determinants on $\mathrm{PM}_{2.5}$ concentrations using a two-step panel quantile regression. Applied Energy, 272, 115246. https:/doi.org/10.1016/j.apenergy.2020.115246

Yue, Y. L., Tian, L., Yue, Q., \& Wang, Z. (2020). Spatiotemporal variations in energy consumption and their influencing factors in China based on the integration of the DMSP-OLS and NPP-VIIRS nighttime light datasets. Remote Sensing, 12(7), 1151. https://doi.org/10.3390/rs12071151 
Zeng, Y. Y., Cao, Y. F., Qiao, X., Barnabas, C. S., \& Tang, Y. (2019). Air pollution reduction in China: Recent success but great challenge for the future. Science of The Total Environment, 663, 329-337. https://doi.org/10.1016/j.scitotenv.2019.01.262

Zhang, Q. L., \& Seto, K. C. (2011). Mapping urbanization dynamics at regional and global scales using multi-temporal DMSP/OLS nighttime light data. Remote Sensing of Environment, 115(9), 23202329. https://doi.org/10.1016/j.rse.2011.04.032

Zhang, W. W., Zhao, B., Gu, Y., Sharp, B., Xu, S. C., \& Liou, K. N. (2020). Environmental impact of national and subnational carbon policies in China based on a multi-regional dynamic CGE model. Journal of Environmental Management, 270, 110901. https://doi.org/10.1016/j.jenvman.2020.110901

Zhang, Y., \& Chen, J. J. (2020). An empirical study of the efficiency of haze pollution governance in Chinese cities based on streaming data. Science of the Total Environment, 739, 139571. https://doi.org/10.1016/j.scitotenv.2020.139571

Zhao, J. C., Ji, G. X., Yue, Y. L., Lai, Z. Z., Chen, Y. L., Yang, D. Y., Yang, X., \& Wang, Z. (2019). Spatiotemporal dynamics of urban residential $\mathrm{CO} 2$ emissions and their driving forces in China using the integrated two nighttime light datasets. Applied Energy, 235, 612-624. https://doi.org/10.1016/j.apenergy.2018.09.180

Zhao, Q., \& Yuan, C. H. (2020). Did haze pollution harm the quality of economic development? - An empirical study based on China's $\mathrm{PM}_{2.5}$ concentrations. Sustainability, 12(4), 1607. https://doi.org/10.3390/su12041607

Zheng, H. Z., \& Xu, L. Y. (2020). Production and consumption-based primary $\mathrm{PM}_{2.5}$ emissions: Empirical analysis from China's interprovincial trade. Resources, Conservation and Recycling, 155, 104661. https://doi.org/10.1016/j.resconrec.2019.104661 